\title{
Discussion Paper No. 15-027 \\ Are SRI Funds Conventional Funds in Disguise or do They Live up to Their Name?
}

Christin Nitsche and Michael Schröder

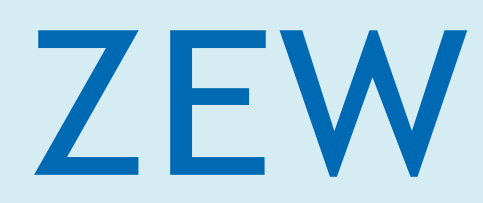

Zentrum für Europäische Wirtschaftsforschung $\mathrm{GmbH}$ Centre for European Economic Research 
Discussion Paper No. 15-027

\title{
Are SRI Funds Conventional Funds in Disguise or do They Live up to Their Name?
}

\author{
Christin Nitsche and Michael Schröder
}

Download this ZEW Discussion Paper from our ftp server:

http://ftp.zew.de/pub/zew-docs/dp/dp15027.pdf

Die Discussion Papers dienen einer möglichst schnellen Verbreitung von neueren Forschungsarbeiten des ZEW. Die Beiträge liegen in alleiniger Verantwortung der Autoren und stellen nicht notwendigerweise die Meinung des ZEW dar.

Discussion Papers are intended to make results of ZEW research promptly available to other economists in order to encourage discussion and suggestions for revisions. The authors are solely responsible for the contents which do not necessarily represent the opinion of the ZEW. 


\title{
Are SRI funds conventional funds in disguise or do they live up to their name?
}

\author{
Christin Nitsche ${ }^{\mathrm{a}}$ \\ Michael Schröder ${ }^{\mathrm{b}}$
}

\begin{abstract}
In recent years, the socially responsible investing (SRI) industry has become an important segment of international capital markets by incorporating ESG (Environmental, Social and Governance) factors into investment selection and management processes. This study analyses whether SRI mutual funds are conventional funds in disguise or invest in line with their ESG objectives. In contrast to other studies, the analysis exclusively focuses on the non-financial performance of SRI vis-à-vis conventional funds and applies ESG corporate ratings of three rating agencies (Oekom, Sustainalytics and ASSET4) to a European and global fund universe. The SRI and nonSRI funds are analyzed with respect to differences in their Top 10 fund holdings, their average ESG rankings and the significance of rating differences by utilizing crosssectional regressions. At a first glance, the top holdings of both fund types seem very similar, but the results of the ranking analysis show that SRI funds have on average higher ESG rankings. Additionally, the cross-sectional regressions show that the ESG rating differences between SRI funds and conventional funds are significantly positive, i.e. SRI funds exhibit higher ESG ratings than conventional funds. These findings are robust as they hold for every single ESG factor and total scores and as well as across the different ratings applied.
\end{abstract}

Keywords: Mutual funds; socially responsible investments; ESG performance; ESG ratings

JEL- Classification: G11; G23; G24; M14

${ }^{\text {a }}$ Frankfurt School of Finance \& Management, Frankfurt/Main, Germany

b Zentrum für Europäische Wirtschaftsforschung (ZEW), Mannheim, and Frankfurt School of Finance \& Management, Frankfurt/Main, Germany schroeder@zew.de 


\section{Introduction}

In recent years, driven by overhauling capital investment decision-making, the socially responsible investing (SRI) industry has become an important segment of international capital markets. Globally, more than 13.6 trillion USD professionally managed assets incorporate ESG (Environmental, Social and Governance) factors into their selection and management process (GSIA, 2012). ${ }^{1}$ Europe is by far the largest region with about 8.8 trillion US Dollar (65 percent) of the known SRI assets under management (AuM). ${ }^{2}$ The SRI fund industry plays an increasingly large role in this evolving segment ${ }^{3}$. For investors it is interesting to know whether these funds invest in line with their objectives or whether they are rather conventional funds in disguise.

Today's academic literature on SRI mainly focuses on the financial performance of ESG screened funds and compares their risk-adjusted returns to those of conventional funds. The majority of these studies finds no difference in the respective performance of fund returns, which raises the question if portfolios of SRI funds are any different from the portfolios of conventional funds. However, hitherto academics have paid little attention to the portfolio compositions and ESG performance of SRI mutual funds. To mention just a few studies, Bello (2005) and Benson et al. (2006) compare general fund characteristics of SRI and non-SRI funds, in particular the total AuM, asset class focus, sector allocation and the market capitalization of companies invested in. The ESG performance of SRI funds and indices compared to their conventional benchmarks is addressed in only two studies by Statman (2006) and Kempf \& Osthoff (2007). Both studies measure the ESG performance by applying social and environmental scores of the rating institution KLD Research and Analysis, Inc. (KLD) to the equities held by the analyzed indices and funds. They find that sustainable investments have higher mean social scores than standard investments. The study at hand will significantly expand the existing literature on the relative ESG performance of SRI funds. On the one hand, the analysis covers two fund data sets - one includes funds that invest in the European market and the other one funds with a global investment universe. On the other hand, ESG corporate ratings of three rating agencies are applied to the fund holdings, in order

\footnotetext{
${ }^{1}$ According to the Global Sustainable Investment Review 2012 (GSIA, 2012), this represents 21.8 percent of the total global assets managed professionally (excluding Latin American regions).

${ }^{2}$ In the European market as much as 49 percent of professionally managed assets incorporate ESG considerations (Eurosif, 2012), compared with only 11 percent of managed assets in the US (US SIF, 2012).

${ }^{3}$ The collective assets of mutual funds identified by the US SIF (2012) doubled from 316 billion to 641 billion US Dollar between 2010 and 2012. The AuM of SRI funds in Europe increased by 19\% in the same two-year period (KPMG, 2013a).
} 
to further test if the results of earlier studies are independent from the rating applied and can be generalized.

The aim of this study is to investigate whether SRI funds are conventional funds in disguise or if they live up to their names and invest in more sustainable equities. The following main research questions are addressed:

(1) Are the Top 10 fund holdings of SRI funds different from the holdings of conventional funds? This is a first step in the analysis of differences in the fund structures.

(2) Do SRI funds have higher ESG rankings than conventional funds? If SRI funds invest in line with their objectives, they should (indeed) have higher ESG rankings than standard funds.

(3) If SRI funds have higher ESG rankings, are the absolute rating differences between SRI and conventional funds statistically significant? Concerning the methodology applied in this thesis, cross-sectional regressions are run in order to test whether SRI funds show significantly positive rating differences compared to standard funds.

\section{$2 \quad$ Literature Review}

In recent years, driven by the increasing demand for responsible investing, the SRI fund industry has evolved to an important part of the international capital markets and attracts interest from researchers, investors and the financial services industry. Their interest is particularly directed towards the financial and non-financial performance of sustainability funds, whereby this study focuses on the assessment of the non-financial performance of SRI compared to non-SRI funds. In this chapter we ask the question which portfolio selection methods SRI fund managers use and if portfolios of SRI funds are any different from the portfolios of conventional funds. The following gives a short summary of the current state of academic research in this field.

When studying ethical investments or SRI, the first discussion evolves around the question which investments deserve this label. Schwartz (2003: 197) claims that the ethical mutual fund industry is not acting in an ethical manner, meaning moral standards or principles such as transparency, accountability and integrity are not met. Investment decisions are based on negative screens, reflecting rather the investors' intended social, religious, or political beliefs than any ethical reasoning. Moreover, he argues that most 
funds do not meet the additional ethical obligations of full and complete disclosure of portfolio selection criteria and fair and non-deceptive marketing (Schwartz, 2003: 211f). A similar distinction was proposed by Mackenzie (1998: 81), who argues that there are ethically significant differences in the way portfolio selection criteria are chosen by funds. While "deliberative” funds choose criteria on the basis of ethical discussion and reasoning, usually carried out by advisory committees, "market-led" funds choose criteria based on their opinion of market demand (Mackenzie, 1998: 82). The two use different portfolio selection methods: value-driven ethical investments use negative or sin screens in order to avoid that controversial stocks and profit-driven SRI funds invest in companies that pass positive screens with high scores on ESG indicators (Derwall, Koedijk, \& Ter Horst, 2010: 1-4). The standard portfolio selection in SRI consists of two steps, first screening sustainability and second financial optimization (Dorfleitner \& Utz, 2012: 155-157). Recent studies suggest how SRI funds could include ESG scores in the portfolio optimization in the second stage (Dorfleitner \& Utz, 2012; Barracchini \& Addessi, 2012).

The study of Chieffe \& Lahey (2009: 65) shows that most SRI mutual funds utilize a combination of positive and negative screens, summarized under the screening concept called "best-in-class". This strategy focuses on sustainability leaders of sectors or industries and is often index-based or oriented towards benchmarks with a wide sector allocation (Von Flotow, 2008: 298). Funds that utilize this portfolio selection method are often criticized, because even the most sustainable company in an industry may not avoid environmental pollution (Schwartz, 2003: 210; Faust \& Scholz, 2008: 152). Moreover, it is argued that the portfolio holdings of such funds may show virtually no difference compared to conventional funds.

This leads to a number of subsequent studies that compare general fund characteristics as well as the portfolio composition of SRI mutual funds with conventional funds.

Bello (2005: 41) analyzes the portfolio characteristics of 42 SRI funds and 84 randomly selected conventional funds. He finds no significant difference between the two groups of funds, neither in the percentage of bonds and stocks in the portfolios nor in the market capitalization of the companies in which they invest. The portfolio constraints of SRI funds do not influence the number of portfolio holdings or the percentage of total assets invested in the top 10 holdings.

The paper of Benson et al. (2006: 337) examines the question whether the portfolio allocation of SRI funds across industries is any different from conventional funds. The 
study finds that the two types of funds invest different percentages of their AuM in different industries, but these differences are not consistent across the time period analyzed, encompassing the years 1994 to 2003. While, for example in 1999, SRI funds invested more in consumer and financial services, in 2001, investments in hardware, telecommunications, utilities, financial services and consumer goods sectors were significantly higher. These results counter the public criticism that SRI funds are conventional funds in disguise and exploit a marketing opportunity (Benson et al., 2006: 348).

The studies of Statman (2006) and Kempf \& Osthoff (2007) analyze and compare the portfolio composition of SRI and conventional indices and funds by applying sustainability scores to the companies included in the index or fund. These scores are provided by the rating institution KLD Research and Analysis, Inc. and are calculated as the sum of a company's scores on the following indicators: corporate governance, community, diversity, employee relations, environment, human rights, product, alcohol, firearms, gambling, military, nuclear and tobacco.

Statman (2006: 101) compares the constituents of the S\&P 500 index to four indices of socially responsible companies: the Domini 400 Social Index, the Calvert Social Index, the Citizens Index, and the U.S. Dow Jones Sustainability Index. He finds that each SRI index has a higher mean score than that of the S\&P 500 index. The study concludes that the list of companies included in SRI indices show a wide range of scores and a high degree of overlap with the S\&P 500 (Statman, 2006: 108). Kempf \& Osthoff (2007) similarly utilize KLD company scores to compare the portfolio holdings of SRI funds to conventional funds concerning their social and environmental standards. The study ranks US equity funds in the time period of 1991 to 2004 according to their ethical rating (based on KLD scores) and shows that SRI funds have a significantly higher ethical ranking than conventional funds. Moreover, the funds are ranked higher with respect to each qualitative characteristic analyzed and the results are stable over time and after controlling for additional fund characteristics (Kempf \& Osthoff, 2007: 13f). However, a study of worldwide SRI and conventional retail funds by Hawken (2004: 16) finds that there is virtually no difference between the cumulative investment portfolios of the two fund types. For example, over 90\% of the Fortune 500 firms are included in SRI funds, causing difficulties for investors to distinguish SRI from conventional funds by the list of the top equity holdings. These results are confirmed by the previously mentioned study of Chieffe \& Lahey (2009), who analyze the top ten 
holdings of 78 SRI funds and count how many times each firm appears. From the 37 most often counted companies, 33 are in the S\&P 500 index and also part of the Fortune 500 firms and 13 are constituents of the Dow Jones Industrial Average (Chieffe \& Lahey, 2009: 66).

While the studies of Statman (2006) and Kempf \& Osthoff (2007) apply KLD scores to evaluate companies' social and environmental performance, an analysis of Wimmer (2013: 10) utilizes the ESG scores of the ASSET4 database of the Thomson Reuters Datastream to analyze the persistence of 27 SRI mutual fund ESG scores in the time period between 2003 and 2009. His study shows that ESG scores of funds remain high for approximately two years, but no empirical evidence of persisting ESG scores after three and four years is found. This lack of persistence is not caused by adverse changes in firms' ESG scores, but driven by a change of funds' portfolio holdings towards lower rated companies (Wimmer, 2013: 12ff).

Our study will significantly expand the existing knowledge of research in two ways: The analyzed fund universe is expanded to funds that invest either in the European market or globally. The non-financial performance is measured by utilizing ESG corporate ratings of three different rating agencies: oekom research AG (Oekom), Sustainalytics and ASSET4.

\section{Data: ESG Ratings}

The aim of this chapter is to provide an overview of the ESG data used in the empirical part of the analysis. Like most rating agencies, the three institutions at the focus of this study, i.e. oekom research AG (Oekom), Sustainalytics and ASSET4, also assess the sustainability of companies based on three pillars: environmental, social and governance. In the first subchapter the concepts of the ESG ratings are described, whereas the second subchapter discusses the characteristics of the ESG rating data.

\subsection{Concepts of the ESG ratings}

Oekom distinguishes between the two main dimensions social and environmental. Both dimensions are further subdivided into three categories each. The social rating is comprised of the sub-ratings for staff \& suppliers, society \& product responsibility, and corporate governance \& business ethics. The environmental pillar is broken down into the categories environmental management, products \& services, and eco-efficiency. The assessment of a company's performance in these categories is based on 700 criteria out 
of which 100 are specifically selected, partially depending on the industry. The relation between industry specific indicators and criteria used across all industries is approximately 35:65 (Windorfer, 2011: 13).

Sustainalytics' corporate ratings are similarly based on the three ESG pillars subdivided into different numbers of categories. Environmental evaluations are based on the assessment of a company's operations, supply chain, and its products. Indicators around employees, customers, supply chain, and the community are reviewed under the social pillar. The governance score results from the analysis of the company's governance, business ethics, and public policies. All described categories subordinated to the ESG pillars are evaluated based on a total of approximately 60 to 100 indicators, depending on the industry in which the company operates (Observatoire sur la Responsabilité Sociétale des Entreprises (ORSE), 2012b: 4). In this process, Sustainalytics distinguishes between core indicators that are used for the evaluation of every company in all peer groups and industry-specific indicators applied to a particular peer group (van den Heuvel, 2012: 15).

ASSET4's company research includes over 750 criteria covering all aspects of sustainability reporting, which are subsequently summarized into 280 key performance indicators (KPIs). The categories resource reduction, emission reduction, and product innovation are subcomponents of the environmental rating. The social score is based on eight categories: employment quality, health \& safety, training \& development, diversity, human rights, community, and product responsibility. The board structure, compensation policy, board functions, shareholder rights, and vision \& strategy are reviewed for the assessment of the company's corporate governance. In addition to the ESG pillars used by all three analyzed rating agencies, ASSET4 adds a fourth economic pillar to its company analysis, which is based on the categories client loyalty, performance, and shareholder loyalty (Thomson Reuters ASSET4, 2014).

All three agencies base their company assessment exclusively or at least mainly (ASSET4) on the three ESG pillars. Table 1 summarizes the ratings and the subcategories for the three rating agencies. 


\begin{tabular}{|c|c|c|c|}
\hline $\begin{array}{l}\text { Corporate } \\
\text { Rating Criteria }\end{array}$ & Oekom & Sustainalytics & ASSET4 \\
\hline \multirow{3}{*}{ Environmental } & Environmental Management & Operations & Resource Reduction \\
\hline & Products \& Services & Products \& Services & Product Innovation \\
\hline & Eco-efficiency & Supply Chain & Emission Reduction \\
\hline \multirow{7}{*}{ Social } & \multirow{4}{*}{ Staff } & \multirow{4}{*}{ Employees } & Employment Quality \\
\hline & & & Health \& Safety \\
\hline & & & Training \& Development \\
\hline & & & Diversity \\
\hline & Suppliers & Supply Chain & Human Rights \\
\hline & Society Responsibility & Community \& Philanthropy & Community \\
\hline & Product Responsibility & Customers & Product Responsibility \\
\hline \multirow{6}{*}{ Governance } & \multirow{4}{*}{ Corporate Governance } & \multirow{4}{*}{ Corporate Governance } & Board Structure \\
\hline & & & Compensation Policy \\
\hline & & & Board Functions \\
\hline & & & Shareholders Rights \\
\hline & Business Ethics & Business Ethics & \\
\hline & & Public Policy & Vision \& Strategy \\
\hline \multirow{3}{*}{ Economic } & & & Client Loyalty \\
\hline & & & Performance \\
\hline & & & Shareholder Loyalty \\
\hline
\end{tabular}

Table 1: Corporate Rating Criteria Comparison

Source: Author based on data from Oekom, Sustainalytics, and ASSET4

The environmental performance is measured by comparable categories that cover the environmental impacts of a company's products and services as well as the impacts of production processes (e.g. emissions, resource consumption). The granularity of social rating criteria used by ASSET4 is much higher compared to Oekom's and Sustainalytics' critera. While Oekom's and Sustainalytics' categories mainly focus on the three company's stakeholders employees, suppliers and customers or society, ASSET4 uses four separate categories to assess the social performance related to the staff and only analyzes the suppliers with respect to their compliance with human rights (e.g. child labor). A similar pattern can be found when comparing the categories evaluated under the governance pillar. Oekom and Sustainalytics use the broad category corporate governance for the review of a company's board independence and compensation policy, whereas ASSET4 applies more detailed categories for these aspects. In addition, Oekom and Sustainalytics cover the category business ethics, under which for example corruption policies and controversies like bribery and lobbying are analyzed. In ASSET4's rating, these topics are included in only one KPI in the community category under the social pillar (Thomson Reuters ASSET4, 2014). A review of a company's sustainability strategy and reporting standard is carried out in Sustainalytics' and ASSET4's framework, while Oekom has not defined a specific 
category for these topics. As not all corporate rating indicators used by Oekom are publically available, it cannot be clarified if these aspects are covered in one of the other categories.

In summary, all three agencies cover the ESG pillars in their corporate assessments and strong overlaps of the categories subordinated to the environmental and social pillar can be identified. The aspects of corporate governance are only part of the social pillar in Oekom's ratings, while Sustainalytics and ASSET4 analyze this pillar in more detail by assessing a higher number of indicators respectively KPIs.

\subsection{Characteristics of the ESG rating data}

The data set provided by Oekom for research purposes comprises corporate ratings of 682 companies as of March 2012. Oekom, being a German rating agency, has an European focus with more than 59\% of the rated companies located in Europe, Middle East, Africa and only 22\% and 19\% from the American and Asia Pacific area, respectively. Besides the overall ratings, scores for the environmental and social pillar are also available for all companies in the 12-notch rating system (A+ to D-) as well as in numeric ratings ranging from 0 to 4 , with 4 being the highest score. In order to reflect the precise corporate ratings, the numeric scores are used for the analysis and converted into point scores ranging from 0 to 100 , e.g. a rating of 3.5 equals 87.5 (= $3.5 / 4 * 100$ ).

Sustainalytics' corporate rating data for the three ESG pillars are publicly accessible on the website of STOXX ${ }^{4}$, because both companies, Sustainalytics and STOXX, partnered to launch the STOXX Global ESG Leaders Indices, which are based on Sustainalytics' sustainability data. The data set includes 1792 companies, while ESG pillar scores (point scores between 0 and 100) are only available for 1484 companies as of September 2013. The overall company scores, which are not included in the original data set, are calculated by equally weighting the three pillar scores.

ASSET4's ESG research data are available on Thomson Reuters Datastream in any degree of detail (by pillar, category, KPIs, indicators). The total and the four pillar scores are retrieved for the current ASSET4 universe of 3894 companies for year-end 2012 and 2013. While only 1021 company scores (point scores between 0 and 100) can be found for the year 2013, rating data for 3360 companies are available for 2012. The data as of December 2012 will be used for further analysis to allow the application of as many corporate ratings as possible to the fund holdings, in order to reliably evaluate the

\footnotetext{
${ }^{4}$ See http://www.stoxx.com
} 
funds' ESG performance. In comparison to Oekom and Sustainalytics, ASSET4 includes an economic pillar score in the total corporate ratings. In order to align the rating data and evaluate companies solely based on non-financial information, this pillar will be excluded. Similarly to Sustainalytics' overall company scores, ASSET4's ESG scores will be calculated using equal weights for the three remaining subcategories without including the economic subcategory.

When looking at the total ESG and pillar scores (Table 2) of the three rating agencies, several things are worth noting. First, Oekom (O) scores have a smaller range of total [30.9, 81.2] and pillar scores [26.0, 87.5], compared to Sustainalytics (S) and ASSET4 (A), which almost use the entire rating spectrum [0,100]. Consequently, the two data sets show a much higher standard deviation in total ESG $\left(\sigma_{\mathrm{S}}=22.2\right.$ and $\left.\sigma_{\mathrm{A}}=24.2\right)$ and pillar scores, while the average scores of all three agencies are still close together $\left(\mu_{\mathrm{O}}=\right.$ 55.0, $\mu_{\mathrm{S}}=50.0$ and $\mu_{\mathrm{A}}=54.0$ ). Having in mind that Oekom's rating universe is much narrower with a geographical focus on European companies, one could argue that the range and standard deviation differences are the results of dissimilar rating universes.

\begin{tabular}{|c|c|c|c|c|}
\hline $\begin{array}{l}\text { Total Universe } \\
\text { by Rating } \\
\text { Agency }\end{array}$ & Descriptive Statistics & ఏ్̃ & 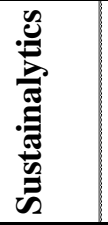 & 点 \\
\hline \multirow{5}{*}{ ESG } & $\mathrm{N}$ & 682 & 1484 & 3360 \\
\hline & Minimum & 30.9 & 3.6 & 4.7 \\
\hline & Maximum & 81.2 & 98.4 & 94.9 \\
\hline & Mean & 55.0 & 50.0 & 54.0 \\
\hline & Standard Deviation & 8.3 & 22.2 & 24.2 \\
\hline \multirow{4}{*}{ Environmental } & Minimum & 26.0 & 0.0 & 8.3 \\
\hline & Maximum & 87.5 & 100.0 & 94.2 \\
\hline & Mean & 54.6 & 50.0 & 53.5 \\
\hline & Standard Deviation & 10.5 & 28.9 & 31.9 \\
\hline \multirow{4}{*}{ Social } & Minimum & 33.2 & 0.0 & 3.6 \\
\hline & Maximum & 82.0 & 100.0 & 97.3 \\
\hline & Mean & 55.4 & 49.9 & 53.0 \\
\hline & Standard Deviation & 8.4 & 28.9 & 30.7 \\
\hline \multirow{4}{*}{ Governance } & Minimum & & 0.0 & 1.3 \\
\hline & Maximum & & 100.0 & 96.8 \\
\hline & Mean & & 50.0 & 55.5 \\
\hline & Standard Deviation & & 28.9 & 29.3 \\
\hline
\end{tabular}

Table 2: Descriptive Statistics of ESG (Sub-) Ratings for Total Universe by Rating Agency. Source: Author's calculations 
In the next step, only the 458 companies that are rated by all three agencies are included in the analysis ${ }^{5}$. In addition to the descriptive statistics, correlations of the total and pillar scores amongst the rating agencies are summarized in Table 3. While Oekom scores still show a smaller range of total [34.9, 77.9] and pillar scores [29.8, 87.5], compared to Sustainalytics' and ASSET4's scores, the standard deviations $\sigma_{\mathrm{S}}=17.1$ and $\sigma_{\mathrm{A}}=12.8$ (Table 3) of Sustainalytics and ASSET4 significantly decrease compared to the total universe analysis with $\sigma_{\mathrm{S}}=22.2$ and $\sigma_{\mathrm{A}}=24.2$ (Table 2). However, the standard deviations are still considerably larger compared to those $\left(\sigma_{O}=8.0\right)$ of Oekom's scores (Table 3). Interestingly, the geographical focus of the matched universe on European companies significantly increases the average ratings of Sustainalytics and ASSET4 to $\mu_{\mathrm{S}}=66.9$ and $\mu_{\mathrm{A}}=79.5$, respectively. This shows that European firms achieve on average higher ESG ratings than their American and Asian-Pacific counterparts that drive down the average Sustainalytics and ASSET4 scores. Oekom's average score for the same matched universe is still around $\mu_{O}=55.7$, which shows that Oekom seems to apply a more rigorous ESG definition and evaluation compared to Sustainalytics and ASSET4.

When correlating Oekom's scores with the ratings of Sustainalytics and ASSET4, the Pearson coefficient is around 0.35 with significance at the 0.001 level (2-tailed). This translates into $\mathrm{R}^{2}$ of around 0.13 , which means that only $13 \%$ of the variance in Oekom's total ESG scores is explained by the variation in Sustainalytics' and ASSET4's ESG scores. The low correlations in the social pillar scores can be explained by the fact that Oekom includes governance indicators in this pillar, while the other agencies report separate governance scores. For the given universe, the Pearson correlation coefficient of Sustainalytics' and ASSET4's total ESG scores is with 0.47 and $\mathrm{R}^{2}$ of 0.22 considerably higher compared to their correlations with Oekom's scores. As mentioned before, this was expected as Oekom's scores are based on only two pillars with industry-specific weightings for the total scores. In addition, governance factors are included as one of three categories of the social pillar, thereby receiving significantly less weight in the total rating.

\footnotetext{
${ }^{5}$ This universe, consisting of 458 companies, is referred to as “Oekom Matched Universe” as the Oekom universe with the lowest number of rated companies is used as the basis.
} 


\begin{tabular}{|c|c|c|c|c|c|}
\hline $\begin{array}{l}\text { Oekom } \\
\text { Matched } \\
\text { Universe }\end{array}$ & $\begin{array}{l}\text { Descriptive Statistics } \\
\qquad(\mathrm{n}=458)\end{array}$ & 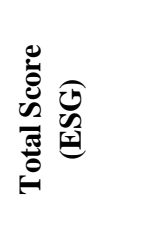 & 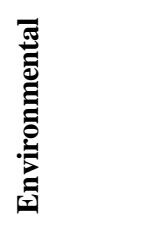 & . & 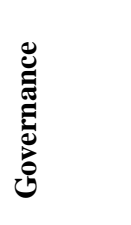 \\
\hline \multirow{4}{*}{ Oekom } & Minimum & 34.9 & 29.8 & 36.3 & \\
\hline & Maximum & 77.9 & 87.5 & 79.2 & \\
\hline & Mean & 55.7 & 55.5 & 55.8 & \\
\hline & Standard Deviation & 8.0 & 10.1 & 8.2 & \\
\hline \multirow{4}{*}{ Sustainalytics } & Minimum & 19.7 & 5.4 & 0.0 & 0.6 \\
\hline & Maximum & 98.4 & 100.0 & 99.9 & 100.0 \\
\hline & Mean & 66.9 & 70.8 & 65.4 & 64.6 \\
\hline & Standard Deviation & 17.1 & 22.9 & 25.4 & 26.5 \\
\hline \multirow{4}{*}{ ASSET4 } & Minimum & 18.3 & 15.7 & 11.2 & 4.6 \\
\hline & Maximum & 94.5 & 94.2 & 97.1 & 96.8 \\
\hline & Mean & 79.5 & 86.3 & 84.0 & 68.1 \\
\hline & Standard Deviation & 12.8 & 11.8 & 15.6 & 26.4 \\
\hline \multirow{2}{*}{$\begin{array}{l}\text { Oekom vs. } \\
\text { Sustainalytics }\end{array}$} & Pearson & $0.353^{* * *}$ & $0.224^{* * *}$ & $0.376^{* * *}$ & \\
\hline & $\mathrm{R}^{2}$ & 0.125 & 0.050 & 0.142 & \\
\hline \multirow{2}{*}{\begin{tabular}{|l|} 
Oekom vs. \\
ASSET4 \\
\end{tabular}} & Pearson & $0.356^{* * *}$ & $0.249^{* * *}$ & $0.403^{* * *}$ & \\
\hline & $\mathrm{R}^{2}$ & 0.127 & 0.062 & 0.162 & \\
\hline \multirow{2}{*}{\begin{tabular}{|l} 
Sustainalytics \\
vs. ASSET4
\end{tabular}} & Pearson & $0.474^{* * *}$ & $0.398^{* * *}$ & $0.349^{* * *}$ & $0.319^{* * * *}$ \\
\hline & $\mathrm{R}^{2}$ & 0.224 & 0.159 & 0.122 & 0.102 \\
\hline
\end{tabular}

*** correlation significant at the 0.001 level (2-tailed)

Table 3: Descriptive Statistics of ESG (Sub-) Ratings for Oekom Matched Universe

Source: Author's calculations

In summary, the analysis has shown that Oekom seems to use a more rigorous ESG definition (following the Frankurt-Hohenheimer guidelines), which leads to lower average ESG scores, smaller ranges and lower correlations with the ratings of Sustainalytics and ASSET4. The ESG scores of these two agencies show stronger relationships (higher correlations), both with large ESG ranges and standard deviations, and different average scores. One should bear in mind these fundamental rating differences when applying ratings to the equity holdings of European and global funds.

\section{$4 \quad$ Data: Funds}

The analysis is based on two main fund data sets, both focusing on active, open-end funds with an asset class focus on equities. The Bloomberg fund database is used for the fund selection and the retrieval of the portfolio holdings. The first data set is limited to equity funds with a geographical focus on the "European Region”, "Eurozone” and "European Union". For the second data set, the geographical criterion is set to "International” and "Global” funds. Both data sets consist of an equal number of SRI and conventional funds. SRI funds are selected by applying positive screens for the 
general attribute 'ESG' and 'Socially Responsible'. Vice versa, negative screens for these two attributes are used to create the conventional European and global fund universe. Appendix 1 shows the resulting number of SRI and conventional funds in both data sets after the application of the described filter criteria. Some subsequent adjustments had to be applied in order to ensure the comparability of the data sets:

\section{European Funds}

- Out of the 67 selected European SRI funds, 7 funds are excluded as portfolio holdings are not available for 5 funds. The remaining 60 SRI funds are part of the final European fund data set.

- Out of the 175 filtered European conventional funds, 60 funds are randomly selected, in order to generate a balanced European fund data set comprised of an equal number of SRI and conventional funds.

\section{Global Funds}

- Out of the 130 selected global SRI funds, 11 funds are excluded because of holding data availability issues, resulting in 119 SRI funds included in the final global fund data set.

- For the global conventional fund universe the asset class allocation filter is adjusted to $100 \%$ equities to downsize the fund universe. Out of the remaining 362 global conventional funds, 119 funds are randomly selected, yielding a balanced global fund data set.

The portfolio holdings of all funds including equity name, international securities identification number (ISIN) and the weightings of the equities within the funds as of December 31, 2013 are retrieved from Bloomberg. The ESG corporate ratings of Oekom, Sustainalytics, and ASSET4 will be subsequently combined with the funds' data using the ISIN as matching criterion. The detailed research methodology and analysis results will be discussed in the next section.

\section{$5 \quad$ Empirical Analysis}

This chapter combines the theoretical considerations regarding ESG corporate ratings with the fund data analysis by applying the rating data to the selected funds in order to evaluate their non-financial performance. The aim is to investigate whether SRI funds are conventional funds in disguise or invest in line with their objective. First, the research questions are summarized, accompanied with the methodologies applied during the data analysis. Next, the research results will be discussed. 


\subsection{Hypotheses}

In the first step, the fund data for a total of 358 funds are combined with the ESG ratings using the companies' ISIN codes. For each fund, the portfolio weights for the equities for which rating data is available, are computed. If not all portfolio holdings are rated, the portfolio weights for rated equities are adjusted so that they sum up to $100 \%$.

Using this approach implicitly assumes that the holdings, which are not rated by the respective rating agency, obtain the average rating ${ }^{6}$ of the rated assets in the fund. The value-weighted pillar and ESG ratings of the funds are calculated using the adjusted equity weights. The pillar and total ESG ratings of all SRI and conventional funds included in the European and global fund data set are calculated using Oekom's, Sustainalytics' and ASSET4's data. Funds that cannot be rated by a rating agency because ESG corporate rating data for the fund's holdings are not available, will be subsequently excluded in the respective fund analysis of that rating agency. Based on the ESG fund rating data sets the following research question (Q) will be investigated, for the European fund universe and the global funds separately.

\section{Research Question 1:}

Are the Top 10 portfolio holdings of SRI funds any different from the holdings of conventional funds?

Investors are usually interested in which companies a fund invests and may gain a first impression by looking at the Top 10 fund holdings. Consequently, this study aims to analyze if the holdings of SRI and conventional funds are any different at first glance. For that purpose, it is determined how frequently a company is included in the Top 10 fund holdings of SRI and non-SRI funds. The 20 most often counted companies in each fund type will be compared with each other.

\section{Research Question 2:}

Do SRI funds have higher ESG rankings on average than conventional funds?

In this step of the analysis, all SRI and conventional funds in the respective data set are ranked based on their total ESG fund ratings. The ranking is normalized so that the ranks are equally distributed between 0 and 1. The fund with the highest ESG rating obtains the $1^{\text {st }}$ rank and the fund with the lowest rating rank 0 . Next, the SRI and conventional funds are clustered into 10-quantiles (deciles) according to their rankings.

\footnotetext{
${ }^{6}$ The process of replacing missing data with the mean of that variable for all other cases is called "mean imputation”.
} 
Finally, the percentage of funds in each decile is calculated. These steps are repeated for the ESG fund ratings based on each rating agency, separately. If SRI funds invest in line with their objective, one would expect that these funds have higher ESG rankings than their conventional counterparts. Consequently, the percentage of SRI funds in the top deciles should be above the share of conventional funds.

\section{Research Question 3:}

If SRI funds have higher ESG rankings, are the absolute rating differences between SRI and conventional funds statistically significant?

While Q1 and Q2 only give a first impression of the differences between SRI and conventional funds with respect to their sustainability, next a formal test, analyzing whether the differences in the ratings are statistically significant, will be conducted. The statistical significance of rating differences is not only tested for the total ESG ratings of the three agencies studied, but also for each pillar score by running the following crosssectional regression:

$$
\operatorname{Rating}_{i ; j}=\beta_{0 ; j}+\beta_{1 ; j} * D_{i}+\varepsilon_{i ; j}
$$

The Rating ${ }_{i ; j}$ denotes the rating in the category $j^{7}$ of fund $i$ and $D_{i}$ is a dummy variable that takes on the value 1 for SRI funds and 0 otherwise. The constant $\beta_{0 ; j}$ takes on the value of the average rating for the analyzed category $j$ of the conventional funds and the coefficient $\beta_{1 ; j}$ measures the rating difference in the respective pillar or total score between SRI and non-SRI funds. By calculating p-values, the statistical significance of the constant $\beta_{0 ; j}$ and the coefficient $\beta_{1 ; j}$ is tested at the $0.1 \%, 1 \%$ and $5 \%$ level indicated by $* * *, * *, *$, respectively.

\subsection{Results}

In the following section, the fund data sets are analyzed following the research methodologies described above and the results are discussed for the European and the global fund universe.

The European fund data set is comprised of 60 SRI funds, for the global funds we identified 119 SRI funds. As described in section 4 we randomly selected 60 and 119 conventional funds, respectively, to represent the characteristics of the European and

\footnotetext{
7 The analyzed categories $j$ are the three pillars ("E" = environmental pillar; "S" = social pillar; "G" = governance pillar) and the total score ("ESG”).
} 
global funds not focusing on SRI. After combining the funds' holdings data with the ESG ratings, funds without any ESG rating are excluded from the respective analysis. ${ }^{8}$

\subsubsection{Research Question 1: Differences in the Top 10 fund holdings}

Firstly, the research question is addressed if the top 10 SRI fund holdings of European and global sustainability funds are different from conventional funds. For that purpose, the Top 10 fund holdings of European and global funds are analyzed with respect to the most popular companies in SRI and non-SRI funds. The 20 equities that are most often counted in European funds are reported in Table 4 for SRI funds and Table 5 for conventional funds. The companies' counts as well as the ESG ratings, they received from the ratings agencies Oekom, Sustainalytics and ASSET4 are listed in columns 3 6.

\begin{tabular}{|c|c|c|c|c|c|}
\hline $\begin{array}{l}\text { Top Fund } \\
\text { Holdings }\end{array}$ & European SRI Funds & Count & $\begin{array}{l}\text { Oekom } \\
\text { Rating }\end{array}$ & $\begin{array}{c}\text { Sustain- } \\
\text { alytics } \\
\text { Rating }\end{array}$ & $\begin{array}{c}\text { ASSET4 } \\
\text { Rating }\end{array}$ \\
\hline & SANOFI & 31 & 63.8 & $\overline{80.6}$ & 87.7 \\
\hline 2 & BNP PARIBAS & 27 & 46.7 & 91.9 & 91.7 \\
\hline & ROCHE HOLDING AG-GENUSSCHEIN & 22 & 62.3 & 72.6 & 80.0 \\
\hline & SAP SE & 21 & 68.3 & 72.9 & 92.4 \\
\hline & AXA SA & 21 & 60.0 & 82.2 & 89.9 \\
\hline & ALLIANZ SE-REG & 20 & 62.9 & 96.1 & 89.7 \\
\hline & SIEMENS AG-REG & 19 & 67.6 & 69.4 & 89.4 \\
\hline & NOVARTIS AG-REG & 19 & 64.2 & 72.5 & 83.8 \\
\hline & BAYER AG-REG & 17 & 57.6 & 65.5 & 77.8 \\
\hline 10 & BASF SE & 15 & 66.6 & 75.6 & 80.6 \\
\hline 11 & VODAFONE GROUP PLC & 15 & $\mathbf{n} / \mathbf{a}$ & $\mathbf{n} / \mathbf{a}$ & $\mathbf{n} / \mathbf{a}$ \\
\hline 12 & TOTAL SA & 14 & 67.6 & 39.4 & 81.9 \\
\hline 13 & BANCO BILBAO VIZCAYA ARGENTA & 12 & 52.7 & 82.4 & 87.4 \\
\hline 14 & BG GROUP PLC & 11 & 62.8 & 87.4 & 83.4 \\
\hline 15 & DAIMLER AG-REGISTERED SHARES & 10 & 64.1 & 69.0 & 83.1 \\
\hline 16 & NESTLE SA-REG & 10 & 59.3 & 74.9 & 84.8 \\
\hline 17 & ING GROEP NV-CVA & 9 & 44.4 & 85.6 & 89.2 \\
\hline 18 & UNILEVER NV-CVA & 9 & 62.1 & 79.3 & 86.7 \\
\hline 19 & HSBC HOLDINGS PLC & 8 & 47.5 & $\mathbf{n} / \mathbf{a}$ & 85.3 \\
\hline 20 & GLAXOSMITHKLINE PLC & 7 & 67.1 & 68.9 & 91.2 \\
\hline & Minimum & & $\overline{44.4}$ & 39.4 & 77.8 \\
\hline & Maximmm & & 68.3 & 96.1 & 92.4 \\
\hline & Mean & & 60.4 & 75.9 & 86.1 \\
\hline
\end{tabular}

Table 4: Top Fund Holdings of European SRI Funds

Source: Author's calculations

\footnotetext{
${ }^{8}$ European fund universe exclusions: Oekom and Sustainalytics = 1 SRI, 2 conventional , ASSET4: no exclusion. Global fund universe exclusions: Oekom = 2 SRI, 5 convenstional, Sustainalytics: 2 SRI, 3 conventional, ASSET4: 1 SRI and 2 conventional funds.
} 
Table 4 shows that Sanofi is under the Top 10 fund holdings of more than half of the analyzed European SRI funds, closely followed by BNP Paribas (27 counts) and Roche (22 counts). However, Oekom and ASSET4 have actually given SAP, with 68.3 points (pts) and 92.4pts, the maximum ESG score of the 20 most often counted companies and Sustainalytics evaluates Allianz (96.1pts) as the most sustainable company. These two companies are found in approximately one third of the analyzed European SRI funds. Based on Oekom's rating, the 20 most counted companies have an average rating of $\mu \mathrm{O}$;ESG $=60.4$, which is 5.4pts above the average rating of the total Oekom universe. Sustainalytics' and ASSET4's assessments yield an average rating of $\mu S$; ESG = 75.9 and $\mu \mathrm{A} ; \mathrm{ESG}=86.1$, actually 25.9pts and 32.1pts above their total universe averages. These huge differences are mainly driven by the fact that their total universe is comprised of significantly more non-European companies that generally have lower ESG ratings than European companies.

In comparison to Table 4, Table 5 reports the 20 most often counted companies in the Top 10 holdings of European conventional funds. It is remarkable that Sanofi and Roche are again at the top of the list and included in top fund holdings of 25 and 17 conventional funds, respectively. The average ESG ratings of the 20 listed companies are below the ones of the most counted companies in SRI funds, but still above the universe averages of the three rating agencies. This finding suggests that also fund managers of conventional funds select companies with above average ESG ratings. However, the companies may not be chosen by conventional fund managers because of sustainability considerations but because of good risk-return profiles.

When comparing both lists, it becomes clear that 15 of 20 companies show up under the most often counted companies of SRI and conventional funds. Consequently, at the first glance, an investor may have difficulties to recognize differences in the Top 10 fund holdings, when comparing SRI and non-SRI funds. The tables can only be distinguished by the 5 companies marked in the above tables by gray-shaded fields. Here, it can at least be seen that SRI funds seem to avoid companies that generate revenues from alcohol (Anheuser-Busch) and tobacco (British American Tobacco) and may cause environmental harm (BP and Airbus), while these companies frequently show up in conventional fund. However, one may raise the question why so many European SRI funds invest in Total, an oil and gas company, similar to BP. The 2013 returns of Total compared to BP could be an argument for a purely return-driven investor, but are a questionable approach for SR investors. Overall, the holding-based analysis suggests 
that SRI funds are perhaps disguised conventional funds as the frequently included equities in the Top 10 holdings of SRI and non-SRI funds are very similar.

\begin{tabular}{|c|c|c|c|c|c|}
\hline $\begin{array}{l}\text { Top Fund } \\
\text { Holdings }\end{array}$ & European Conventional Funds & Count & $\begin{array}{l}\text { Oekom } \\
\text { Rating }\end{array}$ & $\begin{array}{c}\text { Sustain- } \\
\text { alyties } \\
\text { Rating }\end{array}$ & $\begin{array}{c}\text { ASSET4 } \\
\text { Rating }\end{array}$ \\
\hline 1 & SANOFI & 25 & 63.8 & 80.6 & 87.7 \\
\hline 2 & TOTAL SA & 18 & 67.6 & 39.4 & 81.9 \\
\hline 3 & ROCHE HOLDING AG-GENUSSCHEIN & 17 & 62.3 & 72.6 & 80.0 \\
\hline 4 & NOVARTIS AG-REG & 16 & 64.2 & 72.5 & 83.8 \\
\hline 5 & BNP PARIBAS & 15 & 46.7 & 91.9 & 91.7 \\
\hline 6 & ALIIANZ SE-REG & 13 & 62.9 & 96.1 & 89.7 \\
\hline 7 & BAYER AG-REG & 13 & 57.6 & 65.5 & 77.8 \\
\hline 8 & HSBC HOLDINGS PLC & 13 & 47.5 & $\mathbf{n} / \mathbf{a}$ & 85.3 \\
\hline 9 & SIEMENS AG-REG & 12 & 67.6 & 69.4 & 89.4 \\
\hline 10 & VODAFONE GROUP PLC & 12 & $\mathbf{n} \mathbf{a}$ & $\mathbf{n} / \mathbf{a}$ & $\mathrm{n} / \mathrm{a}$ \\
\hline 11 & AXA SA & 11 & 60.0 & 82.2 & 89.9 \\
\hline 12 & BP PLC & 10 & 50.5 & $\mathbf{n} / \mathbf{a}$ & 84.9 \\
\hline 13 & NESTLE SA-REG & 9 & 59.3 & 74.9 & 84.8 \\
\hline 14 & AIRBUS GROUP NV & 8 & 58.9 & $\mathbf{n} / \mathbf{a}$ & 84.3 \\
\hline 15 & ANHEUSER-BUSCH INBEV NV & 8 & 48.9 & 56.6 & 78.8 \\
\hline 16 & GLAXOSMITHKLINE PLC & 8 & 67.1 & 68.9 & 91.2 \\
\hline 17 & VIVENDI & 6 & 60.0 & 72.3 & 90.6 \\
\hline 18 & DAIMLER AG-REGISTERED SHARES & 6 & 64.1 & 69.0 & 83.1 \\
\hline 19 & UNILEVER NV-CVA & 6 & 62.1 & 79.3 & 86.7 \\
\hline 20 & BRITISH AMERICAN TOBACCO PLC & 6 & 63.1 & 66.9 & 93.4 \\
\hline & Mimimum & & 46.7 & 39.4 & 77.8 \\
\hline & Maximmm & & 67.6 & 96.1 & 93.4 \\
\hline & Mean & & 59.7 & 72.4 & 86.0 \\
\hline
\end{tabular}

Table 5: Top Fund Holdings of European Conventional Funds Source: Author's calculations

For the global fund universe Table 6 and Table 7 show the 20 equities that are most often counted in each of the fund types (SRI and conventional). Table 6 shows that Google leads the list of the most often counted companies under the Top 10 fund holdings of the analyzed global SRI funds with 28 counts (included in $23.5 \%$ of the funds). This is surprising when looking at the average ratings and ranges of the 20 listed companies. With respect to this benchmark, Google is rated below average by Oekom $\left(\right.$ Google $\left._{\mathrm{O}}=46.0, \mu_{\mathrm{O}}=54.7\right)$ and is the worst rated company by Sustainalytics (Google = 31.5) and ASSET4 (Google $\left.\mathrm{A}_{\mathrm{A}}=52.4\right)$. Microsoft (24 counts), Nestle (22 counts), and Apple (21 counts) follow Google in the list of the frequently included equities in SRI funds and are rated better by all three agencies. Out of the top listed companies, Microsoft $\left(\right.$ Microsoft $\left._{\mathrm{A}}=93.9\right)$ received the best rating from ASSET4, BNP Paribas $\left(\mathrm{BNP}_{\mathrm{S}}=93.9\right)$ from Sustainalytics, and Novartis $\left(\right.$ Novartis $\left._{\mathrm{O}}=64.2\right)$ from Oekom. 


\begin{tabular}{|c|c|c|c|c|c|}
\hline $\begin{array}{l}\text { Top Fund } \\
\text { Holdings }\end{array}$ & Ghobal SRI Funds & Count & $\begin{array}{l}\text { Oekom } \\
\text { Rating }\end{array}$ & \begin{tabular}{c|} 
Sustain- \\
alytics \\
Rating
\end{tabular} & $\begin{array}{c}\text { ASSET4 } \\
\text { Rating }\end{array}$ \\
\hline & GOOGLE INC-CL A & 28 & 46.0 & 31.5 & $\overline{52.4}$ \\
\hline 2 & MICROSOFT CORP & 24 & 54.2 & 42.5 & 93.9 \\
\hline & NESTLE SA-REG & 22 & 59.3 & 74.9 & 84.8 \\
\hline 4 & APPLE INC & 21 & 58.7 & 37.9 & 72.1 \\
\hline & JOHNSON \& JOHNSON & 19 & 57.1 & 63.5 & 92.9 \\
\hline & VODAFONE GROUP PLC & 18 & $\mathbf{n} / \mathbf{a}$ & $\mathbf{n} / \mathbf{a}$ & $\mathbf{n} / \mathbf{a}$ \\
\hline 7 & ROCHE HOLDING AG-GENUSSCHEIN & 18 & 62.3 & 72.6 & 80.0 \\
\hline 8 & JPMORGAN CHASE \& CO & 17 & 43.8 & 60.2 & 80.3 \\
\hline 9 & PROCTER \& GAMBLE CO/THE & 16 & 62.1 & 62.5 & 92.2 \\
\hline 10 & NOVARTIS AG-REG & 14 & 64.2 & 72.5 & 83.8 \\
\hline 11 & CITIGROUP INC & 13 & 43.9 & 62.8 & 78.3 \\
\hline 12 & WELLS FARGO \& CO & 13 & $\mathbf{n} / \mathbf{a}$ & 49.0 & 79.7 \\
\hline 13 & BG GROUP PLC & 12 & 62.8 & 87.4 & 83.4 \\
\hline 14 & GENERAL ELECTRIC CO & 12 & 59.2 & 73.7 & 91.7 \\
\hline 15 & EXXON MOBIL CORP & 11 & 51.9 & 38.4 & 83.1 \\
\hline 16 & BNP PARIBAS & 10 & 46.7 & 91.9 & 91.7 \\
\hline 17 & PEPSICO INC & 9 & 55.1 & 72.6 & 81.0 \\
\hline 18 & PFIZER INC & 9 & 54.9 & 66.4 & 76.4 \\
\hline 19 & HSBC HOLDINGS PLC & 8 & 47.5 & $\mathbf{n} / \mathbf{a}$ & 85.3 \\
\hline 20 & PENTAIR PLC & 8 & $\mathbf{n} / \mathbf{a}$ & $\mathbf{n} / \mathbf{a}$ & $\mathbf{n} / \mathbf{a}$ \\
\hline & Minimum & & 43.8 & 31.5 & $\overline{52.4}$ \\
\hline & Maximum & & 64.2 & 91.9 & 93.9 \\
\hline & Mean & & 54.7 & 62.4 & 82.4 \\
\hline
\end{tabular}

Table 6: Top Fund Holdings of Global SRI Funds

Source: Author's calculations

Overall, the 20 most counted companies have an average Oekom rating of $\mu_{\mathrm{O} \text {;ESG }}=54.7$, which is $0.3 p t s$ below the total universe average. This can be anticipated as Oekom's universe includes more companies from the EMEA regions that achieve on average higher ESG scores. Consequently, it is expected that a global company portfolio performs below average. Sustainalytics' and ASSET4's assessments yield an average rating of $\mu_{\mathrm{S}}=62.4$ and $\mu_{\mathrm{A}}=82.4$, actually $12.4 \mathrm{pts}$ and 28.4pts above their total universe averages. This suggests that the most frequently included companies in global SRI funds are at least more sustainable than the average company.

In comparison to Table 6, Table 7 reports the 20 most often counted companies in the Top 10 holdings of global conventional funds. Google is once more at the top of the list and included in top holdings of 25 out of 119 global conventional funds. When looking at the average ESG ratings of the 20 listed companies, it can be observed that the Oekom average for the conventional fund list $\left(\mu_{\mathrm{O} ; \mathrm{C}}=55.9\right)$ is above the one of the SRI fund list $\left(\mu_{\mathrm{O} ; \mathrm{SRI}}=54.7\right)$. This is astonishing as one would expect that the Top 10 holdings of SRI funds are on average more sustainable than the ones of non-SRI funds. 


\begin{tabular}{|c|c|c|c|c|c|}
\hline $\begin{array}{l}\text { Top Fund } \\
\text { Holdings }\end{array}$ & Ghobal Conventional Funds & Count & $\begin{array}{l}\text { Oekom } \\
\text { Rating }\end{array}$ & $\begin{array}{l}\text { Sustain- } \\
\text { alyties } \\
\text { Rating }\end{array}$ & $\begin{array}{c}\text { ASSET4 } \\
\text { Rating }\end{array}$ \\
\hline $\mathbf{1}$ & GOOGLE INC-CL A & $\overline{25}$ & 46.0 & 31.5 & 52.4 \\
\hline 2 & ROCHE HOLDING AG-GENUSSCHEIN & 19 & 62.3 & 72.6 & 80.0 \\
\hline 3 & APPLE INC & 18 & 58.7 & 37.9 & 72.1 \\
\hline & TENCENT HOLDINGS LTD & 13 & $\mathbf{n} / \mathbf{a}$ & $\mathbf{n} / \mathbf{a}$ & $\mathbf{n} / \mathbf{a}$ \\
\hline 5 & VODAFONE GROUP PLC & 12 & $\mathbf{n} / \mathbf{a}$ & $\mathbf{n} / \mathbf{a}$ & $\mathbf{n} / \mathbf{a}$ \\
\hline & NESTLE SA-REG & 11 & 59.3 & 74.9 & 84.8 \\
\hline 7 & MICROSOFT CORP & 11 & 54.2 & 42.5 & 93.9 \\
\hline 8 & SAMSUNG ELECTRONICS CO LTD & 10 & 62.2 & $\mathbf{n} / \mathbf{a}$ & 72.7 \\
\hline 9 & NOVARTIS AG-REG & 9 & 64.2 & 72.5 & 83.8 \\
\hline 10 & TAIWAN SEMICONDUCTOR MANUF. & 9 & 62.4 & $\mathbf{n} / \mathbf{a}$ & 71.0 \\
\hline 11 & EXXON MOBIL CORP & 9 & 51.9 & 38.4 & 83.1 \\
\hline 12 & JOHNSON \& JOHNSON & 9 & 57.1 & 63.5 & 92.9 \\
\hline 13 & CHINA MOBILE LTD & 8 & 49.1 & 42.5 & 86.7 \\
\hline 14 & AMAZON.COM INC & 8 & $\mathbf{n} / \mathbf{a}$ & 11.8 & 29.9 \\
\hline 15 & GAZPROM OAO-SPON ADR & 7 & $\mathbf{n} / \mathbf{a}$ & $\mathbf{n} / \mathbf{a}$ & $\mathbf{n} / \mathbf{a}$ \\
\hline 16 & CHEVRON CORP & 7 & 51.8 & $\mathbf{n} / \mathbf{a}$ & 80.1 \\
\hline 17 & CHINA CONSTRUCTION BANK-H & 7 & $\mathbf{n} / \mathbf{a}$ & $\mathbf{n} / \mathbf{a}$ & 56.0 \\
\hline 18 & CITIGROUP INC & 7 & 43.9 & 62.8 & 78.3 \\
\hline 19 & HSBC HOLDINGS PLC & 7 & 47.5 & n/a & 85.3 \\
\hline 20 & TOTAL SA & 7 & 67.6 & 39.4 & 81.9 \\
\hline & Minimum & & 43.9 & 11.8 & 29.9 \\
\hline & Maximum & & 67.6 & 74.9 & 93.9 \\
\hline & Mean & & 55.9 & 49.2 & 75.6 \\
\hline
\end{tabular}

Table 7: Top Fund Holdings of Global Conventional Funds Source: Author's calculations

Using Sustainalytics' and ASSET4's rating data, this expectation is fulfilled with $\mu_{\mathrm{S} ; \mathrm{C}}=$ $49.2<\mu_{\mathrm{S} ; \mathrm{ESG}}=62.4$ and $\mu_{\mathrm{A} ; \mathrm{C}}=75.6<\mu_{\mathrm{A} \text {;ESG }}=82.4$. The average ratings of the frequently included companies in conventional funds are 0.8pts below the total universe averages of Sustainalytics and 21.6pts above the averages of ASSET4's total universe.

In order to test if investors would be able to distinguish SRI and non-SRI funds by the Top 10 portfolio holdings, the two company lists will be compared with each other. The companies that show up in only one of the lists are again marked in the above tables by gray-shaded fields. More than half of the listed companies (11 out of 20) show up under the most often counted companies in the top holdings of SRI and non-SRI funds. Investors may only be able to distinguish the two types of funds by the fact that, global SRI funds, similar to European sustainability funds, seem to avoid companies that may cause environmental harm. For example, companies like Gazprom, Taiwan Semiconductor Manufacturing Company and Chevron are not that frequently included in SRI funds. However, following this line of argument, one may also call into question 
why Exxon Mobil, a multinational oil and gas company, is more often included in the Top 10 fund holdings of SRI than non-SRI funds.

To summarize, the global fund analysis also shows that the portfolio holdings of both fund types are very similar and the fund lists can hardly be distinguished by investors at first glance.

\subsubsection{Research Question 2: Comparison of average ESG rankings}

In the next step, the holding-based results are further tested using a fund ranking analysis. All funds are ranked based on their total ESG fund ratings. The ranking is normalized and equally distributed between 0 (fund with worst ESG rating) and 1 (fund with best ESG rating). If SRI funds live up to their names, it is expected that they have higher ESG rankings than conventional funds. In order to test this hypothesis, SRI and conventional funds are clustered into deciles based on their rankings, whereby the percentage of funds in each cluster is calculated. This ranking analysis is carried out separately for each rating agency and the results are summarized in Table 8.

\begin{tabular}{|c|c|c|c|c|c|c|}
\hline \multirow{2}{*}{$\begin{array}{l}\text { European Funds } \\
\text { Sorted in } \\
\text { Deciles }\end{array}$} & \multicolumn{2}{|c|}{ Oekom } & \multicolumn{2}{|c|}{ Sustainalytics } & \multicolumn{2}{|c|}{ ASSET4 } \\
\cline { 2 - 6 } & $\begin{array}{c}\text { Conventional } \\
\text { Funds }\end{array}$ & $\begin{array}{c}\text { SRI } \\
\text { Funds }\end{array}$ & $\begin{array}{c}\text { Conventional } \\
\text { Funds }\end{array}$ & $\begin{array}{c}\text { SRI } \\
\text { Funds }\end{array}$ & $\begin{array}{c}\text { Conventional } \\
\text { Funds }\end{array}$ & $\begin{array}{c}\text { SRI } \\
\text { Funds }\end{array}$ \\
\cline { 3 - 6 } & $19.0 \%$ & $1.7 \%$ & $20.7 \%$ & $0.0 \%$ & $16.7 \%$ & $3.3 \%$ \\
\hline $0.1-0.1$ & $13.8 \%$ & $6.8 \%$ & $15.5 \%$ & $5.1 \%$ & $20.0 \%$ & $0.0 \%$ \\
\hline $0.2-0.3$ & $13.8 \%$ & $5.1 \%$ & $12.1 \%$ & $6.8 \%$ & $6.7 \%$ & $13.3 \%$ \\
\hline $0.3-0.4$ & $5.2 \%$ & $15.3 \%$ & $12.1 \%$ & $8.5 \%$ & $11.7 \%$ & $8.3 \%$ \\
\hline $0.4-0.5$ & $13.8 \%$ & $5.1 \%$ & $13.8 \%$ & $5.1 \%$ & $10.0 \%$ & $10.0 \%$ \\
\hline $0.5-0.6$ & $10.3 \%$ & $10.2 \%$ & $10.3 \%$ & $10.2 \%$ & $5.0 \%$ & $15.0 \%$ \\
\hline $0.6-0.7$ & $6.9 \%$ & $13.6 \%$ & $3.4 \%$ & $16.9 \%$ & $8.3 \%$ & $11.7 \%$ \\
\hline $0.7-0.8$ & $5.2 \%$ & $13.6 \%$ & $5.2 \%$ & $13.6 \%$ & $8.3 \%$ & $11.7 \%$ \\
\hline $0.8-0.9$ & $5.2 \%$ & $15.3 \%$ & $3.4 \%$ & $16.9 \%$ & $8.3 \%$ & $11.7 \%$ \\
\hline $0.9-1.0$ & $6.9 \%$ & $13.6 \%$ & $3.4 \%$ & $16.9 \%$ & $5.0 \%$ & $15.0 \%$ \\
\hline \hline Mean Rank & 0.39 & 0.61 & 0.34 & 0.65 & 0.40 & 0.60 \\
\hline
\end{tabular}

Table 8: European Funds Sorted in ESG Deciles (0-0.1: Lowest ESG Value, 0.9-1.0: Highest ESG Value) by Rating Agency. Source: Author’s calculations

The first column shows the ten clusters between 0 and 1 and the following columns report the percentage of conventional and SRI funds in the respective deciles for each of the rating agencies. For example, the fund rankings based on Oekom's ESG rating data indicate that $19 \%$ of all analyzed conventional funds show up in the lowest decile, while only $1.7 \%$ of the SRI funds are ranked in this decile. A similar distribution in this decile is reported when the fund rankings are based on Sustainalytics' and ASSET4's data. Based on Oekom's and ASSET4's ratings around 65\% and based on Sustainalytics' 
ratings even $74 \%$ of all conventional funds rank in the bottom half $(0-0.5)$. In contrast, SRI funds are primarily ranked in the high deciles and only a few sustainability funds rank in the lower deciles.

The ranking-based analysis indicates that SRI funds have on average higher ESG rankings than their conventional counterparts. The average rank of SRI funds is between 0.60 and $0.65\left(\mu_{\mathrm{O}}{ }^{\mathrm{SRI}}=0.61, \mu_{\mathrm{S}}^{\mathrm{SRI}}=0.65, \mu_{\mathrm{A}}{ }^{\mathrm{SRI}}=0.60\right)$ depending on the rating agency. The respective average rank of standard funds is between 0.34 and $0.40\left(\mu_{O}{ }^{C}=0.39, \mu_{S}{ }^{C}\right.$ $=0.34, \mu_{\mathrm{A}}{ }^{\mathrm{C}}=0.40$ ).

In order to further illustrate this result, the probability is calculated that an investor, who randomly chooses one of the European SRI funds, gets a higher ranked fund than an investor who randomly chooses one of the European conventional funds. 50,000 pairs of SRI and non-SRI funds are drawn randomly for each rating agency. Based on Oekom, Sustainalytics and ASSET4, the SRI funds have a higher ranking in $72.2 \%, 80.8 \%$ and $69.7 \%$ of all cases, respectively. All in all, the ranking-based analysis for European funds disproves the claim that SRI funds are conventional funds in disguise because they have on average higher ESG rankings than standard funds.

Similar to the European fund analysis, the fund ranking analysis is used to investigate the global funds. The global SRI and non-SRI funds are clustered into 10-quantiles based on their ESG rankings, whereby the percentage of funds in each group is calculated. The results of the ranking analysis based on the total ESG fund ratings of Oekom, Sustainalytics and ASSET4 are summarized in Table 9.

\begin{tabular}{|c|c|c||c|c||c|c|}
\hline \multirow{2}{*}{$\begin{array}{l}\text { Global Funds } \\
\text { Sorted in } \\
\text { Deciles }\end{array}$} & \multicolumn{2}{|c|}{ Oekom } & \multicolumn{2}{c|}{ Sustainalytics } & \multicolumn{2}{|c|}{ ASSET4 } \\
\cline { 2 - 6 } & $\begin{array}{c}\text { Conventional } \\
\text { Funds }\end{array}$ & $\begin{array}{c}\text { SRI } \\
\text { Funds }\end{array}$ & $\begin{array}{c}\text { Conventional } \\
\text { Funds }\end{array}$ & $\begin{array}{c}\text { SRI } \\
\text { Funds }\end{array}$ & $\begin{array}{c}\text { Conventional } \\
\text { Funds }\end{array}$ & $\begin{array}{c}\text { SRI } \\
\text { Funds }\end{array}$ \\
\hline $0.0-0.1$ & $14.9 \%$ & $5.1 \%$ & $16.4 \%$ & $5.1 \%$ & $13.7 \%$ & $6.8 \%$ \\
\hline $0.1-0.2$ & $14.0 \%$ & $6.0 \%$ & $16.4 \%$ & $2.6 \%$ & $18.8 \%$ & $0.8 \%$ \\
\hline $0.2-0.3$ & $14.0 \%$ & $6.0 \%$ & $12.1 \%$ & $7.7 \%$ & $13.7 \%$ & $6.8 \%$ \\
\hline $0.3-0.4$ & $9.6 \%$ & $10.3 \%$ & $8.6 \%$ & $11.1 \%$ & $7.7 \%$ & $11.9 \%$ \\
\hline $0.4-0.5$ & $8.8 \%$ & $11.1 \%$ & $10.3 \%$ & $9.4 \%$ & $9.4 \%$ & $10.2 \%$ \\
\hline $0.5-0.6$ & $8.8 \%$ & $11.1 \%$ & $9.5 \%$ & $11.1 \%$ & $6.0 \%$ & $14.4 \%$ \\
\hline $0.6-0.7$ & $9.6 \%$ & $10.3 \%$ & $6.0 \%$ & $13.7 \%$ & $7.7 \%$ & $11.9 \%$ \\
\hline $0.7-0.8$ & $7.0 \%$ & $12.8 \%$ & $10.3 \%$ & $9.4 \%$ & $12.0 \%$ & $8.5 \%$ \\
\hline $0.8-0.9$ & $8.8 \%$ & $11.1 \%$ & $5.2 \%$ & $14.5 \%$ & $6.0 \%$ & $13.6 \%$ \\
\hline $0.9-1.0$ & $4.4 \%$ & $16.2 \%$ & $5.2 \%$ & $15.4 \%$ & $5.1 \%$ & $15.3 \%$ \\
\hline \hline Mean Rank & 0.41 & 0.58 & 0.40 & 0.60 & 0.41 & 0.59 \\
\hline
\end{tabular}

Table 9: Global Funds Sorted in Deciles (0-0.1: Lowest ESG Value, 0.9-1.0: Highest ESG Value) by Rating Agency. Source: Author's calculations

For each decile between 0 and 1, the percentage of conventional and SRI funds for each rating agency is reported. While $14 \%$ to $16 \%$ of the conventional funds are ranked in the 
lowest decile $(0-0.1)$, only $5 \%$ to $7 \%$ of the SRI funds are ranked in that decile depending on the rating agency. A similar trend is observed in the second and third worst categories $(0.1-0.3)$. Based on Oekom's ratings around $61 \%$ and based on Sustainalytics' and ASSET4's ratings even around 64\% of all conventional funds rank in the bottom half $(0-0.5)$. In contrast, SRI funds are primarily ranked in the high deciles. The lower the decile, the fewer SRI funds are in it.

The ranking-based analysis of global funds comes to the same conclusion as the European fund analysis, namely that sustainability funds have on average higher ESG rankings than their conventional counterparts. The average rank of global SRI funds is between 0.58 and $0.60\left(\mu_{\mathrm{O}}{ }^{\mathrm{SRI}}=0.58, \mu_{\mathrm{S}}^{\mathrm{SRI}}=0.60, \mu_{\mathrm{A}}{ }^{\text {SRI }}=0.59\right)$ depending on the rating agency. The respective average rank of conventional funds is between 0.40 and 0.41 $\left(\mu_{\mathrm{O}}{ }^{\mathrm{C}}=0.41, \mu_{\mathrm{S}}{ }^{\mathrm{C}}=0.40, \mu_{\mathrm{A}}{ }^{\mathrm{C}}=0.41\right)$.

One can translate this result again into the probability for an investor, who randomly chooses one of the global SRI funds, to get a higher ranked fund than an investor who randomly chooses one of the global non-SRI funds. For that purpose, 50,000 pairs of global SRI and non-SRI funds are drawn randomly for each rating agency. The SRI fund investor would invest in $68.1 \%$ of all cases in a higher ranked fund when Oekom's rating data is used. The respective probabilities that the investor chooses a better ESG ranked fund using Sustainalytics' and ASSET4's data sets are 67.0\% and 69.3\%, respectively.

All in all, the ranking-based analysis for global funds finds no evidence that sustainability funds are standard funds in disguise, but proves that these funds have on average higher ESG rankings. Nevertheless, sustainability investors should take a closer look at ESG fund ratings because more than one third of the analyzed SRI funds are ranked in the bottom half $(0-0.5)$.

\subsubsection{Research Question 3: Are ESG rating differences significant?}

The results so far have given a fist impression of the similarities and differences between SRI and non-SRI funds. While the Top 10 portfolio holdings of both fund types show significant overlaps, SRI funds obtain on average better ESG rankings than conventional funds. In the last step of the analysis, a formal test is conducted in order to investigate if the rating differences between SRI and non-SRI funds are statistically significant. This test is not only performed for the total ESG ratings of the three 
agencies, but also for each pillar score. The results of the cross-sectional regressions for the European fund universe following equation (2) are summarized in Table 10:

\begin{tabular}{|c|c|c|c|c|}
\hline European Funds & Category (j) & $\beta_{0 ; j}$ & $\beta_{1 ; j}$ & $\mathbf{R}^{2}$ \\
\hline \multirow{3}{*}{ Oekom } & Environmental & $57.234^{* * *}$ & $2.546^{* * *}$ & 0.145 \\
\hline & Social & $56.732^{* * *}$ & $1.315^{* * *}$ & 0.102 \\
\hline & Total Score & $57.082^{* * *}$ & $1.940^{* * *}$ & 0.139 \\
\hline \multirow{4}{*}{ Sustainalytics } & Environmental & $69.074^{* * *}$ & $6.784^{* * *}$ & 0.148 \\
\hline & Social & $65.181^{* * *}$ & $6.416^{* * *}$ & 0.221 \\
\hline & Governance & $66.351^{* * *}$ & $5.190^{* * *}$ & 0.133 \\
\hline & Total Score & $66.869^{* * *}$ & $6.130^{* * *}$ & 0.233 \\
\hline \multirow{4}{*}{ ASSET4 } & Environmental & $82.214^{* * *}$ & $4.779^{* *}$ & 0.085 \\
\hline & Social & $81.002^{* * *}$ & $6.546^{* * *}$ & 0.135 \\
\hline & Governance & $68.582^{* * *}$ & 2.410 & 0.020 \\
\hline & Total Score & $77.482^{* * *}$ & $4.363^{* *}$ & 0.082 \\
\hline
\end{tabular}

${ }^{*} \mathrm{p}<0.05,{ }^{* *} \mathrm{p}<0.01, * * * \mathrm{p}<0.001$

Table 10:ESG-Ratings of European SRI and Conventional Funds by Rating Agency:

Rating $_{i ; j}=\beta_{0 ; j}+\beta_{1 ; j} * D_{i}+\varepsilon_{i ; j .} D_{i}=1$, if ESG Fund, $=0$, if Conventional Fund.

Source: Author's calculations

The first column shows the agencies that provide the ESG corporate ratings applied to the fund holdings. The second column lists the categories (pillar and total ESG score) in which the funds are rated. The estimated constant $\beta_{0 ; j}$ is reported in column 3 and takes the value of the average conventional fund score in the respective category $j^{7}$. The coefficient $\beta_{1 ; j}$ in column 4 measures the rating difference between SRI and non-SRI funds as the dummy variable $D_{i}$ takes on the value of 1 , if a fund is an SRI fund and the value 0 otherwise. ${ }^{* * *}, *^{*}$ and * indicate the significance of the constant $\beta_{0 ; j}$ and the coefficient $\beta_{1 ; j}$ at the $0.1 \%, 1 \%$ and $5 \%$ level. For reasons of completeness, the last column shows the $\mathrm{R}^{2}$ of the respective regression.

Table 10 reveals that the average score of European conventional funds using Oekom's rating data is around 57pts for both pillar scores $\left(\beta_{0 ; \mathrm{E}}=57.234, \beta_{0 ; \mathrm{S}}=56.732\right)$ and the total ESG score $\left(\beta_{0 ; \mathrm{ESG}}=57.082\right)$. The parameter of interest, $\beta_{1 ; j}$, is significantly positive at the $0.1 \%$ level for all Oekom scores $\left(\beta_{1 ; \mathrm{E}}=2.546, \beta_{1 ; \mathrm{S}}=1.315, \beta_{1 ; \mathrm{ESG}}=\right.$ 1.940). Using Sustainalytics' ESG ratings, the average conventional fund total score is around 67pts $\left(\beta_{0 ; \mathrm{ESG}}=66.869\right)$ with higher average scores in the environmental pillar $\left(\beta_{0 ; \mathrm{E}}=69.072\right)$ and lower ratings in the social and governance pillars $\left(\beta_{0 ; \mathrm{S}}=65.181, \beta_{0 ; \mathrm{G}}\right.$ $=66.351$ ). SRI funds show significantly positive deviations (at the $0.1 \%$ level) in all pillar scores $\left(\beta_{1 ; \mathrm{E}}=6.784, \beta_{1 ; \mathrm{S}}=6.416, \beta_{1 ; \mathrm{G}}=5.190\right)$ and in the total ESG score $\left(\beta_{1 ; \mathrm{ESG}}\right.$ 
= 6.130). The European conventional funds obtain an average total ESG score of 77pts $\left(\beta_{0 ; \mathrm{ESG}}=77.482\right)$ using ASSET4's rating data. They score $\beta_{0 ; \mathrm{E}}=82.214$ and $\beta_{0 ; \mathrm{S}}=$ 81.002 in the environmental and social pillar and $\beta_{0 ; \mathrm{G}}=68.582$ in the governance pillar. The sustainable counterparts have significantly positive coefficients in the social score (at $0.1 \%$ level) and in the environmental and total score (at the $1 \%$ level). The impact of the ESG dummy $D_{i}$ is not significantly different from 0 for the governance pillar.

Based on Table 10, one can conclude that SRI funds have higher ratings than standard funds, i.e. European SRI funds are not conventional funds in disguise. This result holds not only for the total ESG scores, but for all pillar scores. The rating differences between SRI and non-SRI funds are smaller when Oekom's ratings are applied, compared to Sustainalytics' and ASSET4's fund rating differences. This can be explained by the fact that Oekom's rating distribution has a significant lower range and standard deviation. In contrast, Sustainalytics' and ASSET4's fund rating distributions are widely spread driven by higher ranges and standard deviations on the corporate ESG rating level.

In summary, the analysis suggests that European SRI funds live up to their names and have higher ESG rankings and rating compared to their conventional counterparts. In the next paragraph, it is tested whether similar conclusions can be drawn for the global fund data set. The results for the global funds are shown in Table 11:

\begin{tabular}{|l|l|r|r|r|}
\hline Global Funds & Category (j) & $\boldsymbol{\beta}_{\mathbf{0} ; \mathbf{j}}$ & \multicolumn{1}{|c|}{$\boldsymbol{\beta}_{\mathbf{1 ; j}}$} & \multicolumn{1}{c|}{$\mathbf{R}^{2}$} \\
\hline \multirow{3}{*}{ Oekom } & Environmental & $56.037^{* * *}$ & $1.793^{* * *}$ & 0.054 \\
\cline { 2 - 5 } & Social & $54.918^{* * *}$ & $2.011^{* * *}$ & 0.088 \\
\cline { 2 - 5 } Sustainalytics & Total Score & $55.471^{* * *}$ & $1.959^{* * *}$ & 0.084 \\
\hline \hline \multirow{5}{*}{ ASSET4 } & Environmental & $56.492^{* * *}$ & $7.379^{* * *}$ & 0.092 \\
\cline { 2 - 5 } & Social & $50.504^{* * *}$ & $7.439^{* * *}$ & 0.107 \\
\cline { 2 - 5 } & Governance & $51.457^{* * *}$ & $4.722^{* * *}$ & 0.058 \\
\cline { 2 - 5 } & Total Score & $52.818^{* * *}$ & $6.513^{* * *}$ & 0.117 \\
\hline \hline & Environmental & $68.666^{* * *}$ & $7.525^{* * *}$ & 0.106 \\
\cline { 2 - 5 } & Social & $65.697^{* * *}$ & $7.328^{* * *}$ & 0.092 \\
\cline { 2 - 5 } & Governance & $66.260^{* * *}$ & $3.296^{*}$ & 0.022 \\
\cline { 2 - 5 } & Total Score & $66.874^{* * *}$ & $6.050^{* * *}$ & 0.104 \\
\hline
\end{tabular}

$* \mathrm{p}<0.05, * * \mathrm{p}<0.01, * * * \mathrm{p}<0.001$

Table 11: ESG-Ratings of Global SRI and Conventional Funds by Rating Agency:

Rating $_{i ; j}=\beta_{0 ; j}+\beta_{1 ; j} * D_{i}+\varepsilon_{i ; j .} D_{i}=1$, if ESG Fund, $=0$, if Conventional Fund. Source: Author's calculations

The cross-sectional regressions using Oekom's rating data show that the average total ESG score of global conventional funds is around 55 pts $\left(\beta_{0 ; \mathrm{ESG}}=55.471\right)$ with an 
average environmental score of $\beta_{0 ; \mathrm{E}}=56.037$ and a social score of $\beta_{0 ; \mathrm{S}}=54.918$. The coefficient $\beta_{1 ; j}$ is significantly positive at the $0.1 \%$ level for all three scores $\left(\beta_{1 ; \mathrm{E}}=\right.$ 1.793, $\left.\beta_{1 ; \mathrm{S}}=2.011, \beta_{1 ; \mathrm{ESG}}=1.959\right)$. This means that a global SRI fund is rated on average approximately 2pts better than a conventional fund by Oekom, which is in line with the difference between both fund types in the European fund data set. Using Sustainalytics’ ESG ratings, the average conventional fund total score is around 53pts $\left(\beta_{0 ; \mathrm{ESG}}=52.818\right)$ with higher average scores in the environmental pillar $\left(\beta_{0 ; \mathrm{E}}=56.492\right)$ and lower ratings in the social and governance pillars $\left(\beta_{0 ; \mathrm{S}}=50.504, \beta_{0 ; \mathrm{G}}=51.457\right)$. The sustainable counterparts show significantly positive coefficients (at $0.1 \%$ level) in all three pillar scores $\left(\beta_{1 ; \mathrm{E}}=7.379, \beta_{1 ; \mathrm{S}}=7.439, \beta_{1 ; \mathrm{G}}=4.722\right)$ and the total ESG score $\left(\beta_{1 ; \mathrm{ESG}}=6.513\right)$. The global conventional funds obtain an average total score of $67 \mathrm{pts}$ $\left(\beta_{0 ; \mathrm{ESG}}=66.874\right)$ using ASSET4's rating data. They score $\beta_{0 ; \mathrm{E}}=68.666$ and $\beta_{0 ; \mathrm{S}}=$ 65.697 in the environmental and social pillar and $\beta_{0 ; \mathrm{G}}=66.260$ in the governance pillar. The SRI funds show significantly positive deviations at the $0.1 \%$ level in the environmental $\left(\beta_{1 ; \mathrm{E}}=7.525\right)$, social $\left(\beta_{1 ; \mathrm{S}}=7.328\right)$ and total ESG scores $\left(\beta_{1 ; \mathrm{ESG}}=6.050\right)$ and at the $5 \%$ level in the governance rating $\left(\beta_{1 ; G}=3.296\right)$.

Three main conclusions can be drawn from Table 11: First, global SRI funds have higher ESG ratings than standard funds and are not conventional funds in disguise. This result is very robust as it holds for all pillar and the total ESG scores as well as across the different ratings applied. Secondly, the absolute rating averages of conventional funds $\left(\beta_{0 ; \text { Oekom }}=55.471, \beta_{0 \text {; Sustainalytics }}=52.818, \beta_{0 \text {; ASSET4 }}=66.874\right)$ are all above the universe averages of the respective rating agency $\left(\mu_{\mathrm{O}}=55.0, \mu_{\mathrm{S}}=50.0, \mu_{\mathrm{A}}=54.0\right)$. This finding suggests that conventional fund managers also overweigh companies with above average ESG ratings, being driven either by sustainability considerations or more likely by attractive risk-return profiles. Thirdly, rating differences between the two types of funds measured by the coefficient $\beta_{0 ; j}$, are smaller for the Oekom fund ratings compared to the differences when Sustainalytics' or ASSET4'S ratings are applied. This is driven by the characteristics of Oekom's ESG ratings, having low ranges and standard deviations. Consequently, the fund rating distributions for global funds are also expected to show lower ranges and rating differences between both fund types. The fund rating distributions of Sustainalytics and ASSET4 are widely spread, driven by higher ranges and standard deviations on the corporate ESG rating level.

In summary, the results of the global fund analysis strengthen the finding of the European fund analysis that SRI funds are not standard funds in disguise. They have on 
average higher ESG rankings as well as ESG ratings compared to their conventional counterparts. Overall, the comparison of the regression results for European and global funds shows that European funds are on average more sustainable than global funds and SRI funds have a better ESG rating than standard funds.

\section{Research Summary}

This chapter summarizes the main analysis results by following the three research questions.

The study focuses on equity mutual funds with a geographical focus either on the European area or with a global investment universe. For both groups of funds, those with the classification "ESG" and "Socially Responsible", are compared with conventional funds. The analysis aims to examine, whether sustainable investment funds are conventional funds in disguise or whether they live up to their names. Three specific research questions have been analyzed and the main findings will be summarized below.

\section{Research Question 1:}

Are the portfolios of SRI funds different from the holdings of conventional funds when focusing on the Top 10 fund holdings?

The study analyzed and compared the equity holdings which are most frequently included under the Top 10 holdings of both types of funds. More than half of the most often counted companies in global conventional funds also appeared on the list of SRI funds, the European fund analysis displaying even more matches. Therefore, at the first glance, an investor may have difficulties to distinguish SRI and non-SRI funds by the Top 10 fund holdings.

Socially responsible investors could be satisfied with this outcome, if all of these companies were sustainable companies with respect to the ESG criteria. However, the ESG corporate ratings of the three agencies are very mixed for some of the companies, and SRI funds can be criticized for frequent investments in companies that have relatively low ESG ratings.

On the other hand, one could give SRI fund managers credit for they excluded companies from the investment universe which generate revenues from alcohol and tobacco or cause environmental harm. However, even here negative examples were 
found. This may be explained by the best-in-class concept used by many sustainable investment funds.

In short, at the first glance, the fund holdings of SRI and non-SRI funds are very similar. From an investor's point of view, it seems doubtful that SRI funds really invest in more sustainable companies than standard funds when looking at the Top 10 fund holdings.

\section{Research Question 2:}

Do SRI funds have higher ESG rankings than conventional funds?

In the second step of the analysis, all funds were ranked based on their total ESG ratings. The rankings are distributed between 0 (worst ESG rated fund) and 1 (best ESG rated fund). The study compared the percentage of sustainability and conventional funds in ten calculated quantiles. If SRI funds invest in line with their objective, they are expected to have on average higher ESG rankings than standard funds.

This hypothesis was confirmed for the European as well global fund data set, in which SRI funds ranked on average around 0.20 better than their conventional counterparts, independent from the rating agency. While more than $60 \%$ of the conventional funds ranked in the bottom half $(0-0.5)$ at any given point in time, SRI funds are primarily ranked in the higher deciles. The lower the decile, the fewer SRI funds are in it.

Nevertheless, from an investor's point of view, it is worthwhile to look at the ranking of the SRI fund of his choice as there are also sustainable funds that rank even below conventional funds. For the European data set an investor choosing randomly amongst SRI and conventional funds has a probability of about $30 \%$ and for the global funds about 33\% to select an SRI fund with an ESG rating that is below the conventional fund.

\section{Question 3:}

If SRI funds have higher rankings, are the absolute rating differences between SRI and conventional funds statistically significant?

While the previous research findings suggest that SRI funds have on average higher ESG rankings compared to non-SRI funds, a formal test, analyzing whether the differences in the ratings are statistically significant, was conducted in the last step of the analysis. Cross-sectional regressions were run for each category $j$ by rating agency yielding a constant $\beta_{0: j}$ and a coefficient $\beta_{1 ; j}$ (see equation (2)). 
The constant, $\beta_{0 ; j}$, reports the average ESG rating of conventional funds which is higher for the European fund data set compared to the global funds, irrespective of the rating agency.

The parameter of main interest, $\beta_{1 ; j}$, measures the rating difference between SRI and non-SRI funds for the analyzed sub-scores and the total ESG rating. If socially responsible investment funds keep what their names promise, the coefficient $\beta_{1 ; j}$ should be significantly positive. This hypothesis was confirmed for the total ESG ratings of the European as well as global fund data sets for all ESG ratings applied. In general, SRI funds are rated better than their conventional benchmarks independent from the geographical focus of the fund. In addition, the reported coefficients $\beta_{1 ; j}$ are not only significantly positive for the total ESG scores, but for almost all sub-scores analyzed.

At the first glance, the absolute rating differences between both fund types seem to be small. This is mainly due to the best-in-class approach applied by many SRI funds. Following this concept, sustainability funds may invest in the best rated company of an industry with on average poor sustainability measures, while conventional funds may also include, for example, the second and third best companies. Thus, SRI funds are only able to outperform conventional funds by some rating points (between the first and second/third best company), as the ESG company ratings in one industry are often narrowly distributed. Hence, larger rating differences between the two fund types cannot be expected as long as most funds rely on best-in-class concepts.

In summary, the cross-sectional regressions showed that the rating differences between SRI funds and conventional funds are significantly positive, i.e. SRI funds are not conventional funds in disguise but exhibit a significantly higher weight on those companies with a relatively high ESG rating. 


\section{Appendix}

\begin{tabular}{|c|c|c|c|c|}
\hline \begin{tabular}{|l|} 
Fund \\
Selection
\end{tabular} & Filter & Criterion & $\begin{array}{c}\text { SRI } \\
\text { Funds }\end{array}$ & $\begin{array}{c}\text { Conventional } \\
\text { Funds }\end{array}$ \\
\hline \multirow{8}{*}{ 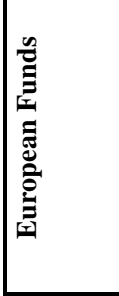 } & Market Status & Active & 224,669 & 224,669 \\
\hline & Fund Primary Share Class & Yes & 105,824 & 105,824 \\
\hline & Fund Type & Open-End Funds & 76,834 & 76,834 \\
\hline & Asset Class Focus & Equity & 18,766 & 18,766 \\
\hline & Asset Class Allocation & Equity $>95 \%$ & 11,795 & 11,795 \\
\hline & Fund Geographical Focus & European Region, Eurozone, European Union & 1,209 & 1,209 \\
\hline & General Attribute & + / - ESG, Socially Responsible & 67 & 175 \\
\hline & Adjustments & After Exclusions / Random Selection & 60 & 60 \\
\hline \multirow{8}{*}{ 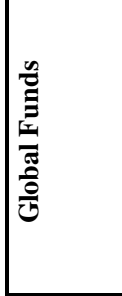 } & Market Status & Active & 224,669 & 224,669 \\
\hline & Fund Primary Share Class & Yes & 105,824 & 105,824 \\
\hline & Fund Type & Open-End Funds & 76,834 & 76,834 \\
\hline & Asset Class Focus & Equity & 18,766 & 18,766 \\
\hline & Asset Class Allocation & Equity > 95\% / Equity > 100\% & 11,795 & 1,510 \\
\hline & Fund Geographical Focus & Global, International & 3,144 & 375 \\
\hline & General Attribute & + / - ESG, Socially Responsible & 130 & 362 \\
\hline & Adjustments & After Exclusions / Random Selection & 119 & 119 \\
\hline
\end{tabular}

Appendix 1: Fund Selection Criteria

Source: Author based on data from Bloomberg (2014) 


\section{Reference List}

AA1000 Framework. (1999). AA1000 Framework. Standard, guidelines and professional qualification. Retrieved from: http://www.accountability.org/aboutus/publications/aa1000-framework.html

Barracchini, C., \& Addessi, M. E. (2012). Ethical Portfolio Theory: A New Course. Journal of Management and Sustainability, 2(2), 35-42.

Bello, Z. Y. (2005). Socially Responsible Investing and Portfolio Diversification. The Journal of Financial Research, 28(1), 41-57.

Benson, K. L., Brailsford, T. J., \& Humphrey, J. E. (2006). Do Socially Responsible Fund Managers Really Invest Differently? Journal of Business Ethics, 65(4), 337357.

Care Group AG. (2012). Care Group: How we rate Sustainability Funds. Zurich, Switzerland: Care Group AG. Retrieved from: http://www.caregroup.ch/_FundRating_E.pdf

Capelle-Blancard, G., \& Monjon, S. (2012). Trends in the Literature on Socially Responsible Investment: Looking for the Keys under the Lamppost. Business Ethics: A European Review, 21(3), 239-250.

Chieffe, N., \& Lahey, K. E. (2009). Helping Clients Select SRI Mutual Funds and Firms. Journal of Financial Planning, 22(2), 60-70.

Derwell, J., Koedijk, K., \& Ter Horst, J. (2011). A Tale of Values-Driven and ProfitSeeking Social Investors. Journal of Banking \& Finance, 35(8), 1-41.

Deutsche Bank Climate Change Advisors (DBCCA). (2012). Sustainable Investing: Establishing Long-Term Value and Performance. Retrieved from: https://www.deutsche-bank.de/cr/en/docs/Sustainable_Investing_2012--Establishing-long-term-value-and-performance.pdf

Dorfleitner, G., \& Utz, S. (2012). Safety first portfolio choice based on financial and sustainability returns. European Journal of Operational Research, 221(1), 155164.

European Social Investment Forum (Eurosif). (2012). European SRI Study 2012. Retrieved from http://www.eurosif.org/publication/view/european-sri-study-2012/

Faust, M., \& Scholz, S. (2008). Nachhaltige Geldanlagen. Faust M./Scholz S.(Hrsg.): Nachhaltige Geldanlagen: Produkte, Strategien und Beratungskonzepte. Frankfurt am Main, Germany: Frankfurt School Verlag, 133-156.

FERI EuroRating Services AG (FERI). (2014). Das Feri Fondsrating. Bad Homburg, Germany: FERI EuroRating Services AG. Retrieved from: http://fer.feri.de/Content/Frr/Files/Fondsplattform/PUBLICARCHIVE/Fondsratin g.pdf 
Forum Nachhaltige Geldanlagen e.V. (2008). Das Europäische Transparenzlogo. Berlin, Germany: Forum Nachhaltige Geldanlagen e.V. Retrieved from: http://www.forum-ng.org

Global Sustainable Investment Alliance (GSIA). (2012). Global Sustainable Investment Review 2012. Retrieved from: http://gsiareview2012.gsialliance.org/pubData/source/Global\%20Sustainable\%20Investement\%20Alliance. pdf

Hawken, P. (2004). Socially Responsible Investing. Sausalito, CA: Natural Capital Institute. Retrieved from: http://www.ebscohost.com

ISO. (2010). ISO 26000 - Social Responsibility. Retrieved from: http://www.iso.org/iso/home/standards/iso26000.htm

Kempf, A., \& Osthoff, P. (2008). SRI Funds: Nomen est Omen. Journal of Business Finance \& Accounting, 35(9-10), 1276-1294.

Koellner,T., Weber, O., Fenchel M., \& Scholz, R. (2005). Principles for Sustainability Rating of Investment Funds. Business Strategy and the Environment, 14(1), 5470 .

KPMG. (2013a). European Responsible Investing Fund Survey 2013. Retrieved from: http://www.kpmg.no/arch/_img/9834869.pdf

KPMG. (2013b). The KPMG Study of Corporate Responsibility Reporting 2013. Retrieved https://www.kpmg.com/Global/en/IssuesAndInsights/ArticlesPublications/corpora te-responsibility/Documents/corporate-responsibility-reporting-survey-2013-execsummary.pdf

Mackenzie, C. (1998). The Choice of Criteria in Ethical Investment. Business Ethics: A European Review, 7(2), 81-86.

Mercer. (2007). The Language of Responsible Investment: An Industry Guide to Key Terms and Organisations. New York, NY: Mercer Investment Consulting, Inc. Retrieved http://www.merceris.com/uploads/documents/20079417574200710111757413970 .pdf

Morningstar. (2014). Morningstar Analyst Rating for Funds. Retrieved from: http://www.morningstar.com/InvGlossary/morningstar-analyst-rating-forfunds.aspx

Natural Investments (NI), LLC. (2014). The Heart Rating. Retrieved from: http://www.naturalinvestments.com/heart-rating/

Novethic. (2013). Overview of ESG Rating Agencies. Retrieved from http://www.novethic.fr/fileadmin/user_upload/tx_ausynovethicetudes/pdf_comple ts/2013_overview_ESG_rating_agencies.pdf 
Novethic. (2014). The SRI Label. Retrieved from: http://www.novethic.com/sociallyreponsible-investment/french-european-sri/sri-market.html

Observatoire sur la Responsabilité Sociétale des Entreprises (ORSE). (2012a). Guide to Sustainability Analysis Organisations: Oekom Research. Paris, France: ORSE.

Observatoire sur la Responsabilité Sociétale des Entreprises (ORSE). (2012b). Guide to Sustainability Analysis Organisations: Sustainalytics. Paris, France: ORSE.

Oekom Research AG. (2014). Oekom Corporate Rating: IBM. Munich, Germany: Oekom Research AG.

Rayner Spencer Mills Research (RSMR). (2014). A Guide to Sustainable and Responsible Investing. Retrieved from: http://www.sriservices.co.uk/wpcontent/uploads/1404-SRI-Guide-final-Adviser-Guide.pdf

Ribando, J. M., \& Bonne, G. (2010). A New Quality Factor: Finding Alpha with ASSET4 ESG Data (Starmine Research Note). New York, NY: Thomson Reuters. Retrieved from: $\quad$ http://thomsonreuters.com/products/financialrisk/content/07_008/starmine-quant-research-note-on-asset4-data.pdf

SAM/SPG Sustainability Leadership Award. (2010). BHP Brugger and Partners LTD. Retrieved from: http://www.bruggerconsulting.ch/en/p79000275.html

Schaefer, H. (2005). International Corporate Social Responsibility Rating Systems: Conceptual Outline and Empirical Results. Journal of Corporate Citizenship, 20, 107-120.

Schaefer, H, Beer, J., Zenker, J., \& Fernandes, P. (2006) Who is who in Corporate Social Responsibility Rating? A survey of internationally established rating systems that measure Corporate Responsibility. Guetersloh, Germany: Bertelsmann Foundation.

Schwartz, M. S. (2003). The “Ethics” of Ethical Investing. Journal of Business Ethics, 43(3), 195-213.

Sparkes, R. (2001). Ethical investment: whose ethics, which investment? Business Ethics: A European Review, 10(3), 194-205.

Statman, M. (2006). Socially Responsible Indexes: Composition, performance, and tracking error. The Journal of Portfolio Management, 32(3), 100-109.

Sustainalytics. (2014). HSBC Holdings plc ESG Report. Amsterdam, Netherlands: Sustainalytics.

The Forum for Sustainable and Responsible Investment (US SIF). (2012). Report on Sustainable and Responsible Investing Trends in the United States 2012. Retrieved from: http://www.ussif.org/files/Publications/12_Trends_Exec_Summary.pdf

The Global Reporters. (2004). Risk \& Opportunity: Best Practice in Non-Financial Reporting. London, United Kingdom: The Global Reporters 2004 Survey of Corporate Sustainability Reporting. Retrieved from: 
http://www.unep.fr/shared/publications/pdf/WEBx0111xPA-

RiskOpportunity04.pdf

Thomson Reuters ASSET4. (2014). Environmental, Social \& Governance (ESG) Data. Retrieved from: http://extranet.datastream.com/data/ASSET4\%20ESG/Index.htm

Thomson Reuters Datastream, accessed July 2014.

Triple Bottom Line. (2009, November 17). The Economist. Retrieved from: http://www.economist.com/node/14301663

UBS Financial Services Inc. (UBS). (2013). Sustainable Investing. New York, NY: UBS Financial Services Inc. Retrieved from: http://www.ubs.com/content/dam/WealthManagementAmericas/documents/UBSResearch-Focus-Sustainable-Investing-July2013.pdf

United Nations Environment Programme Finance Initative (UNEP FI). (2004). The Materiality of Social, Environmental and Corporate Governance Issues to Equity Pricing. Genève, Switzerland: UNEP Finance Initiative. Retrieved from: http://www.unepfi.org/fileadmin/documents/amwg_materiality_equity_pricing_re port_2004.pdf

Van den Heuvel, R. (2012). How Robust are CSR Benchmarks? Comparing ASSET4 with Sustainalytics (Master's Thesis). Tilburg University, Netherlands. Retrieved from http://arno.uvt.nl/show.cgi?fid=127705

Vigeo. (2012). Green, Social and Ethical Funds in Europe: 2012 Review. Retrieved from: http://www.vigeo.com/csr-ratingagency/images/PDF/Publications/green_social_and_ethical_funds_in_europe_201 2.pdf

Von Flotow, P. (2008). Nachhaltige Publikumsfonds im deutschsprachigen MarktKonzepte und gute Gründe. Faust/Scholz (Hg.): Nachhaltige Geldanlagen: Produkte, Strategien und Beratungskonzepte. Frankfurt am Main, Germany: Frankfurt School Verlag, 293-309.

Wimmer, M. (2013). ESG-persistence in Socially Responsible Mutual Funds. Journal of Management and Sustainability, 3(1), 9-15.

Windorfer, R. (2011). Das Nachhaltigskeitsrating der oekom research AG (PowerPoint presentation, July 18, 2011). Munich, Germany: TU Munich. Retrieved from: http://fwl.wzw.tum.de/fileadmin/Downloads/TUM_Bwl/TUM_2011_07_18_RW. ppt.pdf

Wood, D., \& Hoff, B. (2007). Handbook on Responsible Investment Across Asset Classes. Boston, MA: Institute for Responsible Investment at the Boston College Center for Corporate Citizenship. Retrieved from: http://www.thegiin.org/binarydata/RESOURCE/download_file/000/000/50-1.pdf

World Commission on Environment and Development. (1987). Our common future. Oxford, United Kingdom: Oxford University Press. Retrieved from: http://www.un-documents.net/our-common-future.pdf 